\title{
TRABALHO E DESENVOLVIMENTO
}

(HOMENAGEM A UM MESTRE)

PROF. GARLOS ALBERTO BARATA SILVA (*)

Nos primeiros anos da década de sessenta e até sua investicura como Ministro do Pretório Excelso, o Professor Eloy José da Rocha, em sua cátedra na Faculdade de Direito de Pôrto Alegre, da Universidade Federal do RGS, preocupava-se, sobremodo, com os problemas do desenvolvimento e muito especialmente com as conseqüências que trariam no fato social - trabalho, nas relações jurídicas entre empregados e empregadores e, finalmente, no surgimento de novas condições de trabalho e correlata elaboração de nôvo ordenamento jurídico.

Suas aulas, no período mencionado, especialmente ao tratar da parte introdutória do Direito do Trabalho, tinham a marca de autênticas criações doutrinárias, baseadas em profundas e exaustivas pesquisas que, fornecendo-lhe os elementos fáticos, permitiramlhe, como analista profundo, a construção de uma doutrina de desenvolvimento aplicada ao trabalho.

Lastimàvelmente, deixando de atender aos reiterados apelos de várias gerações de estudantes que tiveram a ventura de aurir seus ensinamentos, nunca quis o eminente Mestre desenvolver, por escrito, os esquemas que com tanto carinho preparava para suas magníficas preleções. Eu mesmo, então como seu Assistente, rogueilhe por diversas vêzes que escrevesse livros, que deixasse para os seus alunos a oportunidade de terem sempre à mão os seus ensinamentos, os seus conceitos e o seus pensamentos, brotados de profunda meditação e de sua extraordinária cultura jurídica. Tudo porém foi em vão.

Diga-se, até mesmo, numa homenagem à modéstia do ilustre mestre, que, não fôsse a obrigatoriedade da apresentação de tese

* Professor de Direito do Trabalho. 
para realização de seu concurso de cátedra, talvez todos nós, lidadores do Direito do Trabalho, não tivéssemos a oportunidade de conhecer a melhor obra de doutrina editada em nosso País, na especialidade, que é a sua "A Extinção do Contrato de Trabalho".

Contudo, não foram poucos os alunos que, contrariando mesmo as solicitações do mestre, conseguiram por vários meios, por a. pontamentos de aulas, por notas taquigráficas e até por gravações feitas clandestinamente, fixar seus pensamentos que, se naquela oportunidade representavam criações ousadas e até certo modo com a marca da antevisão para o futuro, hoje, exatamente hoje, no momento em que ingressamos definitivamente na faixa do desenvolvimento industrial, maior valor possui exatamente pela confirmação verificada diàriamente do acêrto dos conceitos emitidos quando tudo era previsão e expectativa.

E exatamente por estas razões é que os seus seguidores na Cátedra do Direito do Trabalho renovam a cada ano, evidentemente sem o brilho do mestre, aquêles ensinamentos que, cada dia que passa, mais atuais se tornam.

Ao receber a solicitação da Direção de nossa Faculdade de apresentar um trabalho para publicação em sua Revista, tive os olhos voltados para o meu eminente mestre de Direito do Trabalho, cuja figura de Magistrado e cultor do Direito faço questão de evocar neste momento, numa homenagem àquele que foi - e continua sendo - o professor de todos nós. Seus ensinamentos trazem a marca inconfundível das idéias grandes e verdadeiras, que o tempo só faz confirmar. São dêle substancialmente - e às vêzes até textualmente - as noções que exporemos a seguir no estudo da evolução e das atuais perspectivas do Direito do Trabalho.

$$
\text { . }
$$

problema da intervenção do Estado em matéria de trabalho foi relativamente simples até o século XIX porque, mesmo no sen tido jurídico, o trabalho não tinha, até então, a relevância hoje apresentada.

Ainda não existia a grande indústria. Havia uma indústria incipiente. As relações intersubjetivas originadas pelo trabalho $\mathrm{e}$ ram, por isso mesmo, singelas e não ditavam ao Estado senão pequenas intervenções, quase sempre esporádicas.

Essas intervencões provinham da conveniência de se regularem pelo Poder Público certos fatos econômicos, sociais e políticos mas que não chegavam a se traduzir em fatos de grande relevância. Eram apenas aspectos particulares, que visavam sobretudo a solução imediata de problemas eventuais.

Os Estados modernos, muito ao contrário, defrontam-se com um complexo extraordinário de relações de trabalho, que envolvem condições especialíssimas, criando situações realmente difíceis para a estrutura jurídica das nações e, ao mesmo tempo, exigindo crescente intervenção do Estado nos domínios do trabalho.

Essa intervenção pode ser interpretada de várias maneiras, das quais citaremos três: $1^{\circ}$ ) a intervenção justifica-se como autodefesa do próprio Estado; $2^{\circ}$ ) a intervenção é devida como proteção ao trabalho; $3^{\circ}$ ) a intervenção visa a proteger o homem, que é o único prestador de trabalho, tal como o entendemos no mundo do Direito.

Conviremos, inicialmente, que se processou a evolução nes. se assunto através de três fases distintas.

A primeira fase, até o início do século XIX, caracterizou-se pela intervenção apenas em casos esporádicos, sendo que a industrialização era incipiente ou nula. Prevaleciam, sem qualquer objeção, os conceitos de liberalismo.

Por essa época, deu-se a primeira Revolução Industrial, marcada pelo aparecimento das máquinas e pela aplicação das idéias de Smith e Taylor sôbre a divisão do trabalho e o aumento da produtividade industrial.

A máquina exerceu influência decisiva sôbre a evolução dos métodos de trabalho e sôbre a atitude do Estado face às relações interpessoais oriundas do mesmo. Inicialmente, quando a máquina tinha pouca expressão, os problemas não se apresentavam com tanta intensidade. A escassez de mão-de-obra e a pequena indústria faziam com que todos tivessem oportunidade de adquirir o necessário para o seu sustento.

Quando, porém, a máquina começou a substituir os homens e a reduzir o número dos que tinham trabalho, avolumaram-se os problemas: o desemprêgo, as reivindicações de salário (diante da concorrência de mão-de-obra) e as reivindicações em tôrno da jornada de trabalho. Foram, principalmente, êsses fatos e suas manifestações que ditaram a intervenção do Estado. A concentração das massas trabalhadoras, em situação difícil, gerou a solidariedade e abriu a oportunidade às reivindicações que, freqüentemente, degeneravam em conflitos com os empregadores. Diante disso tudo, os Estados passaram a elaborar as primeiras normas reguladoras do trabalho, como que prevenindo novas convulsões e tentando resolver as dissenções já existentes.

Cabe notar que as reivindicações dos trabalhadores dessa época foram sempre estimuladas por intelectuais, não importando aqui 
o terem sido êstes movidos por intenções demagógicas ou tocados por profundo sentimento humano. Atuando, indiretamente, através de pressões, conseguiram os intelectuais alterar a ordem jurídica vigente, forçando a intervenção do Estado.

Segundo foi mencionado, os primeiros problemas, que surgiram de forma aguda na Inglaterra, na Alemanha e na Franca, foram os de horário e salários. São - como se pode fàcilmente perceber - dois problemas muito ligados: o do ganho e o do tempo em que se ganha. Eram e são questões interligadas.

Foram, portanto, êsses dois aspectos os primeiros a serem propostos às concentrações de trabalhadores, e sôbre êsses dois problemas surgiram as primeiras leis reguladoras do trabalho, no sentido atual.

Essas concentrações de trabalhadores se resumiam. inicialmente, em agrupamentos dos empregados das pequenas indústrias d época. Mais tarde começaram a coligar-se os trabalhadores de diferentes indústrias e passaram a fundar sindicatos, os quais foram logo proibidos por lei.

Mas os trabalhadores terminaram por forçar o Estado ou os empregadores à concessão de horários mais reduzid'os ou de salários mais elevados. Para chegarem a êsses resultados, valiam-se os mesmos de greves, sabotagens, etc., enquanto os patrões lançavam mão das despedidas em massa, do "lock-out", etc.

Êsse quadro precedeu a intervenção do Estado, o qual sentiu que em tais conflitos poderia surgir algo que abalasse a sua própria es trutura. E, com vistas à sua defesa, o Estado providenciou, a fim de evitar o abalo.

Posta a questão no plano doutrinário, pergunta-se: o Estado deveria intervir? por quê? Por autodefesa? Para proteger o trabalho? Para proteger o homem?

E indiscutível que o trabalho é um dever social; dever que por assim dizer - surgiu com o homem. Se há êsse dever, forçoso é admitir-se o correspondente dever do Estado, de proporcionar condições para que o mesmo seja cumprido pelo trabalhador.

Assim sendo, essas condições se constituem num direito fun dado na própria natureza humana, pois se o homem tem direito à vida, tem direito, também, aos meios que lhe permitam subsistir. E se uma condição basilar para tanto é o trabalho, e se o trabalho se exerce na sociedade, no Estado, e se êste dispõe de poder para proporcionar as condições necessárias ao exercício do trabalho, tem também o dever de prestá-las ao trabalhador, tem o dever de proporcionar ao homem, único prestador de trabalho para o Direito os meios necessários, para que trabalhe e, assim, sobreviva.

Além dêsse dever, porém, que é permanente, é preciso notar o momento - social, econômico e político - em que aparece a norma destinada à regulação jurídica da prestação de tais condições, por parte do Estado. Esse momento não é o mesmo na História dos diferentes povos. Varia, até, de atividade para atividade, dentro do mesmo povo.

Há povos que, ainda hoje, não dispõem de legislação do trabalho; outros já possuem um ordenamento científicamente construído. Uns têm Código do Trabalho; outros, leis gerais; outros, ainda, contam apenas com algumas normas de Direito do Trabalho que, em tais casos, não atingiu ainda a sua autonomia científica e legislativa. Para essa diversidade de situações contribuem as dife. rencas de desenvolvimento econômico, social e político, bem como a difusão e as discussões de ideologias.

Sobretudo depois da Primeira Guerra Mundial, os povos em geral e o Brasil em particular passaram a olhar com mais cuidado o problema do trabalho e o da legislação que o deve regular. Foi então que se começou a dar tratamento científico a tais assuntos, inclusive buscando-se os princípios embasadores do Direito do Trabalho.

Tôdas as Constituicões modernas ferem de frente o problema do trabalho e no Brasil, temo-lo nas Constituições de 1934, de 1937 e muito especialmente no art. 157 da Constituição de 1946, no art. 158 da Constituição de 1967 e, agora, no art. 165 da Emenda Constitucional $\mathrm{n}^{\circ} 1$

Além dos dois aspectos apontados - proteção ao trabalhador e ao homem - é preciso acrescentar que a evolução dos aconte. cimentos, no mundo todo, conduz a uma intervenção sempre maior do Estado no setor do trabalho. Também, como ficou dito, essa intervenção não é sincronizada entre os diversos povos e nem simultânea em tôdas as espécies de atividades, condicionada que está a intervenção - a diversidades econômicas, sociais e políticas. Típico exemplo é o que ocorre com a emprêsa dedicada à indústria extrativa ou transformativa de produtos minerais ou vegetais ou animais. Para o plantio de vegetais ou a criação de animais, requerse grandes extensões de terra, onde a densidade de habitantes é escassa. $\mathrm{O}$ trabalhador, conseqüentemente, quase não vê seu colega, comunica-se pouco com êle, e não se capacita tanto da penosidade intrínseca do trabalho. Além disso, o trabalho, nesses ramos, desenvolve-se em locais geralmente salubres, em condições que favorecem a saúde do trabalhador e êste, além do mais, convive com seu patrão, com o mesmo fazendo as refeições ou tomando chimarrão e recebendo, muitas vêzes, a solidariedade, que o auxilia a resolver seus problemas particulares.

Acrescente-se a isso que não se forma uma hierarquia rígida, mas nota-se apenas um comando geral ao qual se subordinam todos os empregados. Aponta-se, ainda, a falta de braços, especial- 
mente hoje, quando os trabalhadores rurais abandonam o campo e se dirigem à cidade, buscando melhores condições de vida e se terá marcante o contraste entre tal quadro e o da indústria extrativa mineral, que foi objeto, mais cedo e mais intensamente, da intervenção do Estado. A atividade da mineração é exercida por grandes concentrações de trabalhadores, em ambiente confinado, onde são especialmente acentuadas as condições de rudeza, insalubridade e periculosidade, principalmente no subsolo. Normalmente, a afluência de mão-de-obra é grande e as condições de habitação, precárias. Tudo isso favorecendo a solidariedade e encorajando as reivindicações dos trabalhadores.

Ocorre, ademais, outro fator, de ordem sociológica: o Estado, desde há muito detentor de privilégio na exploração dos minérios, costumava, quase sempre, mandar para as minas condenados e escravos. Hoje, em regime de concessão, as minas são exploradas por emprêsas particulares, mas nem por isso os mineiros deixam de sentir-se desprezados, sob permanente vigilância, como os condenados a que sucederam. Em face de tudo isso, a intervenção do Estado na indústria da mineração impôs-se com prioridade lógica $\mathrm{e}$ cronológica sôbre a verificada nos demais setores de atividade.

E preciso notar que a legislação do trabalho rural, no Brasil, nunca surgiu de reivindicações dos trabalhadores que, aliás, nem sindicalizados estavam. A sindicalização dêstes foi algo de artificial, provocado pelo Poder Público, sem que os trabalhadores interessaáos se movimentassem prèviamente. Aliás, as primeiras leis brasileiras sôbre o trabalho dipunham precisamente sôbre o trabalho rural, mas devido à imigração de trabalhadores estrangeiros, que aqui desejavam encontrar proteção legal.

Por conseguinte, as condições em que o trabalho se desenvolve, constituem fator sociológico de alta relevância no surgimento da norma de Direito do Trabalho.

Comparando, também, a indústria extrativa com a manufatureira, vemos que esta se caracteriza, em geral, pela capacidade de poucos empregados executarem tarefas de grande vulto, pela con. centração de indústrias e conseqüentemente de trabalhadores, pelas razões apontadas a respeito da mineração, acrescidas de mais dois problemas: o emprêgo da máquina e o aproveitamento do trabalho da mulher e do menor que, às vêzes, fazem concorrência ao trabalho do próprio homem, para não dizer ao do espôso e do pai.

Esse o quadro da Revolução Industrial, quando o Estado resolveu intervir na questão, quadro êsse caracterizado, em largos traços, pelo liberalismo econômico, pelo individualismo jurídico e pelo princípio da autonomia da vontade.
O quadro acima relatado nos apresenta o surgimento das normas de Direito do Trabalho, com os aspectos atuais, sob a influência de fatôres econômicos - envolvidos pela Revolução Industrial - dos quais provieram conseqüências de alta relevância no campo social e, particularmente, no mundo do trabalho.

Inicialmente, foram os problemas de salário e horário os que se manifestaram, sem serem, porém, os maiores problemas do trabalho, tendo em vista que suas dimensões são meramente materiais. Foram, contudo, os mais palpitantes durante a fase tôda da Primeira Revolução Industrial, compreendida como o complexo de fatos já focalizados e desdobrados desde a Revolução Francesa até a Segunda Guerra Mundial.

A Revolução Francesa postulava um princípio de liberdade exacerbada e irradiou suas manifestações por todo o século passado. O século XX, por sua vez, apresentou-nos problemas políticos, atuais e passados, de excepcional importância, bastando citar entre outros a Primeira Guerra Mundial, a Revolução Russa, o Fascismo na Itália, o Nazismo na Alemanha, a Segunda Guerra Mundial e, mais recentemente, a energia nuclear, a tecnologia e, muito especialmente, a conquista do espaço e da lua.

Nesta altura se altera o campo das indagações, pois jả não mais se trata de defender exclusivamente princípio de liberdade preconizacono no século XIX. Ao lado de fatôres econômicos e políticos, influem os fatôres ideológicos, segundo os princípios defendidos pela esquerda, pela direita, pelo centro e pelos matizes de cada um dêles. Essas correntes ideológicas passam a influir, não há como negar, na edição das normas legislativas referentes ao trabalho.

Por isso, podemos tomar o fim da Segunda Guerra Mundial como o término de uma era, sem esquecer que essa divisão, como tôdas as divisões históricas, são precárias.

Quando começou a Segunda Guerra Mundial, reinava a idéia de que o século $\mathrm{XX}$ era o século do corporativismo, ao estilo $\mathrm{d}_{0}$ corporativismo fascista, sem levar-se em conta que era muito cedo para fazer-se tal afirmação, especialmente porque se estavam vivendo os acontecimentos diretamente vinculados ao corporativismo. $\mathrm{O}$ en. quadramento, a classificacão de uma determinada situação sòmente será possível após a análise serena de seus efeitos e do balanço de seus méritos e deméritos.

Com tal reserva, partiremos para a apreciação do quadro histórico doミ últimos dois séculos e seremos levados a uma observação inevitável da realidade atual, que se apresenta marcada em duas fases distintas: uma, do início da Revolução Industrial ao fim da Segunda Guerra Mundial; outra, de 1945 até os nossos dias.

A transformação que hoje experimentamos, comparável à $\mathrm{Re}$ volução Industrial, é a Revolução Tecnológica ou Segunda Revolu- 
ção Industrial, prenunciada pelo bombardeio das bombas voadoras alemãs sôbre a Inglaterra e pela detonação das bombas atômicas norte-americanas sôbre o Japão.

Mais de vinte e cinco anos depois, resumindo-se os fatos ocorridos desde então, podemos tirar, elementarmente, algumas conclusões: energia atômica, aplicações sem conta da energia nuclear, automatização, conquista do espaço, experiências científicas de largo alcance e, finalmente, a conquista da lua.

Previa-se para 1970 a instalação de uma estação espacial para que $o$ homem chegasse aos demais planetas. Mas a velocidade do progresso tecnológico é vertiginosa, e a previsão foi superada, foi antecipada. Já foi atingido o satélite natural da terra e a tecnologia científica parte para feitos ainda mais espetaculares e imprevisiveis.

Se, no entanto, êsses feitos, sob o prisma da técnica, são de espantar, para o observador social e para o homem do Direito não passam de melancólicas constatações. O que se deseja é a perfeição da máquina, da nave espacial, por exemplo, que permitiu o feito de um dos tripulantes sair para o espaço cósmico, durante o vôo e, posteriormente, alunizar. Um defeito mínimo inutilizaria todo o esfôrço despendido para a execução dêsses engenhos.

Um homem, um ser humano, foi quem executou essa máquina, um homem de ciência, alguém que não aparece, que não recebe as homenagens. E é bom que não seja conhecido o autor dessa maravilha científica e técnica, porque o nome de seu autor é, simplesmente, "o homem".

Melancólico contudo é que êsse mesmo homem, nesta época, não encontre a fórmula da vida, da convivência social, deixando cada vez mais nítido o desnível trágico de nossa época: primarismo em problemas sociais e morais ao lado da perfeição técnica.

Esses, pois, os principais aspectos. Energia atômica, conquista do espaço, automatização, problemas do desenvolvimento quatro idéias que retratam nossa época no plano técnico e cultural, com repercussões no plano moral e econômico.

Necessárias são tais considerações para situarmos o Direito - o Direito do Trabalho - , que veremos agora dentro do mundo de hoje, ainda que sua evolução, desenvolvimento e autonomia sejam relativamente recentes.

Ao examinarmos alguns dos tópicos apontados, vemos que a automatização tomou incremento, de maneira especial, a partir do fim da Segunda Guerra Mundial, quando o interêsse militar não mais recomendou o segrêdo em tôrno de certas conquistas - a do radar, por exemplo, que até 1944 fazia parte dos segredos militares.

Quanto ao desenvolvimento, sabe-se que todos os problemas com êle relacionados prendem-se a fatôres locais. A industrialização depende da energia elétrica; esta, da fôrça hidráulica ou do carvão e, em razão disso, já se cogita da distribuição geográfica das emprêsas, para melhor atender à automatização.

Desde a Conferência Internacional do Trabalho, de 1956, que os estudiosos prendem-se ao estudo da automatização. Naquela Conferência, tanto empregados como empregadores já se mostravam preocupados co mo problema e, no entanto, na Brasil, sòmente agora é que se procura equacionar a questão resultante do surgimento de profundas modificações no campo do trabalho, impostas pela "nossa" revolução industrial e pela automatização.

Se a Era Industrial foi, assim, marcada pela característica da mecanizaçãa, pela substituição do braço humano pela rnáquina, ou, pelo menos, pela paulatina redução da mão-de-obra, o início do século XX trouxe um acréscimo, qual seja, a racionalização do trabalho, que se constituiu num progresso da própria Era Industrial.

Hoje, porém, com a figura da máquina, percebemos, aparentemente, a mesma situação. É, no entanto, fundamental a diferença. Na Era Industrial, com o advento da máquina, efetuou-se a mecanização; a máquina substituiu o braço humano. Agora, con á automatização, subsituiu-se o próprio cérebro humano. As má quinas não são mais dirigidas por homens, mas por outras máquinas e é por isso que tem razão o técnico, que disse serem melancólicas as fábricas de hoje, onde está ausente o homem, com o calor, a vida, e onde se encontram apenas máquinas perfeitíssimas.

Às transformações que assim se processam hoje, deu-se o nome de Revolução Tecnológica. Correto ou impróprio o nome, o certo é que, à base do atual desenvolvimento da tecnologia, esta surgindo nôvo regime econômico, implicando em transformação radical do vigente até agora, e com reflexos sôbre a própria pessoa humana. Isso não é sonho. É uma realidade, evidente nos países mais desenvolvidos, e que entre nós, gradualmente, vai se afirmando, já agora, em certos tipos de atividade.

$\mathrm{Na}$ crise de transição, há sempre o risco de uma transformação também política, como conseqüência da verificada nos planos social e econômico, e isso é o que, principalmente, interessa ao Di reito do Trabalho, já que é o próprio homem que sofre os efeitos não só da máquina - como até 1945 - mas do cérebro eletrônico, que traz uma série de conseqüências na vida comercial e urbana.

Não se pode dizer o que, concretamente, acontecerá, face à transformação que hoje se processa, no sentido da automatização. Pode-se prever determinado número de efeitos, em especial nos setores em que mais a automatização já se faz sentir.

Em primeiro lugar, observa-se um alto grau de capitalização 
da emprêsa. As doutrinas de Adam Smith e outros, acêrca da divisão e especialização do trabalho, tomaram extraordinário impulso. $O$ gigantismo empresarial tende a que a emprêsa se baste a si mesma, produzindo inclusive a matéria prima de que necessita.

Contudo, a emprêsa só poderá tomar tal vulto em virtude de um elevado grau de capitalização, que lhe permita comprar máquinas automáticas de que necessita e cujo custo é, ainda, elevadíssimo. Assim sendo, se, por um lado, a máquina automática aumenta extraordinàriamente a produção, por outro lado, a indústria de fabricacão de tais máquinas ainda não está capacitada a produzílas a baixo custo, o que leva as emprêsas a democratizarem seu capital, convidando a participar da formação do mesmo grande número de pessoas, ou mesmo, o povo em geral. No Brasil, por exemplo, os grupos empresariais abrem, cada vez mais, o quadro de par. ticipantes no capital das emprêsas e o próprio Govêrno estimula tal atitude.

Visa-se, como fase final dêsse processo, a participação dos próprios operários na direção das emprêsas, mediante a co-gestão e a participação nos lucros. Um passo muito significativo, no encami. nhamento da estrutura da emprêsa brasileira para a co-gestão, são os Conselhos de Emprêsa, previstos pelo Anteprojeto de Código do Trabalho, e pelos quais haverá efetiva participação dos operários na gestão dos negócios da emprêsa.

Em segundo lugar, pode-se prever, fàcilmente, que essa automatização criará novas indústrias e novos tipos de trabalho. É o que já se verificou em relação aos artigos de plásticos, elaborados em fábricas a êles dedicadas, que dispõem de máquinas especializadas de alto custo, sendo que, por motivo da fabricação do plástico, impôs-se a criação de profissões novas.

Conclui-se, assim, que, se na indústria decresce a necessidade de mão-de-obra, surgem, em contrapartida, novas indústrias, que criam novas fontes de trabalho. E o mesmo que se disse da in. dústria, pode-se dizer do comércio, cujo exemplo mais típico é o supermercado, o restaurante automático e a lancheria. Ocorre, pois, uma compensação, não se podendo saber, entretanto, qual será o saldo final, se positivo ou negativo.

Em terceiro lugar, o fenômeno da especialização profissional, cujos aspectos mais característicos residem na criação, imposta pelas circunstâncias, de dois tipos inteiramente novos de técnicos: os técnicos em direção ou fiscalização e os técnicos profissionais.

A exigência de técnicos implica na necessidade de escolas que os formem. Não temos, ainda, número suficiente de tais escolas e não possứmos nem mesmo tradição técnica, mediante a qual seria mais fácil proporcionar aos futuros técnicos aprendizagem adequada.
Entretanto, o SENAI, o SESI, o SENAC, o SESC, as Secretarias do Trabalho e de Ação Social e o próprio Ministério do Trabalho, mais recentemente, têm organizado cursos para a formação de m'estres, dirigentes, fiscais e supervisores, cursos de grande valor e significacão, por meio dos quais vai-se tentando resolver o problema. As Universidades instalaram Cursos de Administração de Emprêsas, para dirigentes, que têm contado com grande afluência de alunos. No setor de ensino médio, já existem cursos de maestria e direção de serviços.

Tudo isso, numa visão global, significava um encaminhamento para a especialização técnica, no seu mais alto grau, com todos os seus aspectos positivos fàcilmente perceptiveis, não se podendo, entretanto, esquecer o aspecto negativo aí oculto de que a especialização demasiada fatalmente embrutece o homem e isso pode $e$ deve ser evitado, proporcionando-se aos técnicos oportunidade de adquirirem conhecimentos gerais, a fim de que possuam visão glo bal dos problemas co-relacionados com os do seu setor e mesmo de outros setores de atividade.

Ademais, será necessária uma fase de transição, de adaptação, para que não se passe, de inopino, de um trabalho não qualificado para um trabalho altamente especializado, mòrmente sabendo-se que se deve contar com a variável capacidade de adaptação de cada trabalhador.

Sente-se, também, a ocorrência da despedida de empregados por inadaptação, caso em que o aviso prévio poderia ser antecipado, ou seja, durar mais de trinta dias. Tal situação poderia ocorrer, face à inadaptação de empregados e a não obrigação da emprêsa de manter elementos desnecessários, como também, por outro lado, à consideração da pessoa do empregado e da razão da despedida.

Em quarto lugar, a democratização do capital provocará, e já está provccando, separação entre o capital e a administração da emprêsa. No Brasil, os grupos que enfeixavam o capital estão abrindo oportunidade a que êsse capital passe às mãos de muitos, com o que a propriedade passa de um dono, de um grupo, para uma coletividade.

Separação ainda maior se processa entre o proprietário e os trabalhadores, com a vantagem de que não se conhece, distintamente, quem é o proprietário, individualmente, porquanto o proprietário da emprêsa é a sociedade anônima. Por outro lado, verifica-se, gradativamente, uma aproximação entre os dirigentes e os trabalhadores, o que já se pode notar em tôdas as grandes emprêsas.

Em quinto lugar, tende a reduzir-se o número de trabalhadores e a aumentar o número de máquinas, o que leva ao enfraqueci- 
mento da solidariedade entre os trabalhadores. Tal aspecto é negativo, já que a solidariedade de classe, a solidariedade profissional foi e é a razão de ser do sindicato e, através dêste, do contrato coletivo de trabalho.

Em sexto lugar, possibilita-se a melhoria de salários para todos, já que todos desempenham tarefas que exigem alta qualificação. Entre êsses, salientam-se os administradores e os fiscais, que estão passando a constituir a "nova classe", a classe dos que comandam os capitais de muitos controlando ,administrativamente, os capitais de numerosas coletividades.

Há, portanto, na sociedade de hoje, êsses dois fatos novos a automatização e o desenvolvimento - fatos êsses inseparáveis e cujo exame corresponde a um só processo de estudo.

Se a automatização traz como conseqüência novos padrões de vida e melhores condições de trabalho, os seus efeitos, porém, ain da não podem ser julgados em sua totalidade, por falta - ainda hoje - da necessária perspectiva temporal. Alguns efeitos são previsíveis ou mesmo já sentidos e dados como inevitáveis. Entretanto, novamente é de acentuar-se que a experiência da automati zação é muito nova, realizada sòmente em alguns países e em alguns tipos de atividade, devendo-se, pois, usar de reserva na apreciação das conseqüências que, em futuro próximo ou remoto, acarretará.

Entre os efeitos já perceptíveis está a grande capitalização da emprêsa, exigida pela automatização. É preciso observar que a capitalização de até agora assim como, correspondentemente, a au tomatização, evidentemente não são tudo o que poderão ser dentro de talvez breves anos. As máquinas são substituídas por novas máquinas, mais aperfeiçoadas, e a máquina, hoje moderna, moderníssima, torna-se, ràpidamente, obsoleta, suplantada por outra, mais perfeita ainda.

Como o problema é econômico e há diferenças sensíveis de desenvolvimento, de país a país, a concorrência internacional provocará uma corrida pela automatização e, naturalmente, para a capitalizacão, o que nos leva a temer pela sobrevivência de países que não ultrapassem a fase $\mathrm{d}_{0}$ subdesenvolvimento. $\mathrm{O}$ imperialismo $\mathrm{e}$ conômico tende a acentuar-se e não ficará restrito a certos domínios, como hoje, mas avançará até a absorção, caso os países subdesenvolvidos não atinjam a posição necessária de progresso, ainda em tempo.

Outro problema é o da redução de horas de trabalho porque uma só máquina substitui milhares de trabalhadores e ainda requer menos horas de trabalho por parte dos que a manipulam. Prevê-se, por isso, a redução da semana de trabalho para apenas quatro dias e de conseqüência já se estuda o problema do lazer $\epsilon$ de como o- cupar o trabalhador, nas horas de folga. Não se trata apenas de entretê-lo, de diverti-lo, mas também de conservá-lo - afora outros aspectos - em condições morais sadias.

$\mathrm{O}$ que parece acertado é a progressividade na instalação das grandes máquinas automáticas, para que se atenue a crise provocada pela fase de transição, crise essa que repercute na ordem económica, social e política. A generalização da automatização, necessária hoje, não se deve processar, portanto, de uma hora para outra, nem que tal seja, financeiramente, possível.

A indagação mais grave que esta transição provoca é o receio pela estabilidade do sistema. A periclitação do sistema exigirá maior intervenção do Estado, muito maior do que a exigida pela Revolução Industrial e suas conseqüências, porquanto todos os problemas gerados pela Revolução Industrial, somados, nada são, comparacios com os que hoje nos desafiam.

Êsse problema, o da medida da intervenção do Estado, sempre mais intensamente reclamado pelas condições de vida em sociedade, preocupa, hoje mais do que nunca, os juristas e os políticos que desde 1956 o estudam, intensamente, em reuniões internacionais, nacionais e regionais.

Conforme foi acentuado, a automatização, que já é realidade atual, viva, em alguns países, exige um nôvo sistema, adequado, de formação profissional. Entre nós, o SENAI, o SENAC e outras poucas entidades desempenham esta tarefa, mas abrangem âmbito reduzido diante da insuficiência de meios.

A preparação profissional deve, além disso, planejar-se como sistema de adaptação dos trabalhadores já em serviço, que necessi. tam de certas garantias especiais, já reivindicadas, como:

a) aviso prévio mais longo do que o atualmente em vigor;

b) garantia, por parte da emprêsa, que permita a readaptação em breve lapso de tempo, ou a concessão de abono temporário, até o reemprêgo;

c) prioridade do empregado, para ser reempregado na mesma emprêsa, uma vez readaptado.

Dessa forma, vê-se que a automatização prende-se ao problema do emprêgo - e não tanto ao do desemprêgo. A readaptação, desỉinada a solucionar o problema do desemprêgo, assumiu, nos países mais industrializados, uma feição curiosa, qual seja, a da readaptação do trabalhador de fábrica automatizada, no sentiào rural, ou seja, no sentido inverso ao do êxodo rural.

Com isso pretende-se que o trabalhador saia da cidade para o campo, mediante preparação profissional adequada, acudindo-se, ao mesmo tempo, ao problema do emprêgo e ao da atividade rural. 
As principais sugestões apresentadas são, pois, no sentido da readaptação, ou para a indústria automatizada, ou para o campo e, na segunda hipótese, far-se-ia voltar para o campo a massa de trabalhadores desempregados das cidades, que tantos e tão grandes problemas tem suscitado. Sugere-se, ainda, quanto ao desemprêgo, que se pague um seguro aos desempregados, enquanto não encontrem outra ocupação profissional.

Entre essas medidas, um princípio de política parece certo: a adoção das novas técnicas deve ser progressiva e não instantânea. Ainda que um país pudesse substituir tôdas as suas instalações industriais, de uma hora para outra, não deveria fazê-lo, para evitar efeitos violentíssimos, que daí decorreriam. Com o trabalho de transição, obviam-se os efeitos danosos da mudança.

De outro lado, é certo que a automatização, com tôdas as suas implicações, exige do Estado, mais do que a Era Industrial, uma planificação, uma vez que o Estado não pode ficar indiferente a tão profundas modificações sociais e econômicas.

A intervenção deve, portanto, ser maior, mais profunda, sem o que será impossível a planificação. Resulta aqui o problema fundamental do limite da intervenção do Estado, intervenção essa necessàrianiente maior que na fase atual, constituindo-se num desafio aberto ao político e ao jurista.

Naturalmente, com essa nova forma de intervenção, muda-se todo o ordenamento jurídico. As estruturas jurídicas clássicas, tanto as do Direito Privado como as do Direito Público, não satisfazem mais. E essa modificação de estruturas jurídicas é o problema principal, porquanto nova regulação, nôvo ordenamento jurídico deverá estabelecer-se, de modo a corresponder às fundamentais modificações que a automatização está produzindo $\mathrm{n}_{\mathrm{O}}$ mundo de hoje.

$\mathrm{O}$ próprio Estado não pode mais continuar funcionando nos moldes atuais, porque o mundo em que vive o Estado está mudando. Desde a estrutura estatal, até os direitos individuais, tudo sofrerá modificações.

Não sabemos, como já foi ressaltado, qual será o resultado final de tantas e tão profundas mudanças que hoje se operam no mundo e não há, por outro lado, modêlo para o progresso, nem ideal definido, certo, não se sabendo, também, o ponto a que chegaremos.

Essa consideração geral pode ser estabelecida após as considerações particulares, expendidas acêrca da automatização, dos seus efeitos, e das medidas a tomar com relação a ela.

Outra face da questão é a do desenvolvimento, conexo com o primeiro, mas que deve ser enfocado sob outro ângulo. Problema tão falado, parece, aos desavisados, um simples problema mate- mático, solúvel por esta ou aquela fórmula. Essa, contudo, é a aparência. A verdade é que o problema do desenvolvimento é problema universal, que dá à questão social, desdobrada a partir do século XIX, com a Revolução Industrial, uma nova dimensão.

Todos os conflitos de trabalho, a intervenção do Estado, inicialmente reprimindo as manifestações dos trabalhadores; tolerandoas, depois; depois intervindo, tìmidamente, na regulação das questões de trabalho para, finalmente, intervir, às vêzes até em excesso, com a supressão da própria liberdade - tudo isso, a questão so. cial, que é um drama, assume agora nova dimensão: o desenvolvimento, que se considera, em regra, apenas sob o aspecto econômico.

Realmente, quando se fala em desenvolvimento econômico, tem-se em vista sòmente um aspecto parcial do problema. Raramente o problema do desenvolvimento é considerado num plano global, que lhe abranja todos os aspectos. $E$ isso vale não só para o Brasil, mas, principalmente, para os demais países da América - salvo os Estados Unidos - e para os países novos de modo geral, especialmente os da África, para não confundir-se um aspecto particular com a totalidade: o aspecto econômico do desenvolvimento, com o próprio desenvolvimento que abrange - é bem de ver - outros aspectos.

$\mathrm{O}$ esfôrço dos povos de hoje rumo ao desenvolvimento radica num problema de sobrevivência, o que é explicável, uma vez que, ao falar-se em desenvolvimento, costuma-se apontar os índices de crescimento da produção, em confronto com os índices de crescimento da população. Se o índice de crescimento da população é três vêzes maior que o do crescimento da produção, concluise pelo agravamento do problema da fome. Assim sendo, se hoje $60 \% \mathrm{da}$ humanidade passa a vida inteira sem poder alimentar-se suficientemente, e se a desproporção entre crescimento de população e produção de alimentos é a aludida, vê-se claramente que o problema tende mesmo a se agravar.

Apesar das enormes preocupações, que a realidade de tal situação provoca, ainda assim erra quem confunde o desenvolvimento com a industrialização ou com a mecanização da agricultura. Há alguns anos afirma-se, com freqüência, que o Brasil atingirá uma fase de grande desenvolvimento. Exemplo típico entre nós é a construção de Brasília que, se importou num desenvolvimento considerável sob certos aspectos, por outro lado originou um processo in flacionário que sòmente agora vem sendo debelado.

Quando se fala, pois, em desenvolvimento, pensa-se num setor determinado de atividade e entre nós, particularmente, em industrialização. A industrialização é, sem dúvida, necessária, porém, tratada unilateralmente, levar-nos-á a um êrro fatal. Só haverá desenvolvimento autêntico, no momento em que se alcançar 
desenvolvimento harmônico, desenvolvimento em todos os setores, tanto na agricultura como na indústria, e assim mesmo com as infra-estruturas necessárias. $\mathrm{O}$ objetivo a ter em mira deve ser o da produção agrícola, o desenvolvimento industrial e o progresso de tôdas as demais atividades, que se ligam por sua vez, a outros problemas, como o do mercado.

Se isso é o que ocorre no plano econômico, parece-nos da maior relevância o exame das implicações do desenvolvimento no terreno social. O desenvolvimento, sob qualquer aspecto - transportes, industrialização, produção, agropecuária, etc. - só tem sentido quando se o encara não como fim, mas como meio. $O$ fim é o bem comum, e êsse é de conteúdo social, é a obtenção das condições favoráveis à vida do homem na sociedade. Esse, e sòmente êsse, é o fim do desenvolvimento.

O bem comum não é o bem do Estado, mas ao Estado cabe realizá-lo. E é visando a êsse fim que o desenvolvimento tem sentido. O progresso econômico - industrial ou agrícola - autêntico não se pode alcançar sem o progresso social, que proporcione ao homem, e a todos os homens, as condições mais favoráveis de vida e para tanto o problema do desenvolvimento deve ser examinado num plano harmônico, global, e não como o encaminhamento do País ao crescimento numa atividade única, como seja, por exemplo, a industrialização.

$\mathrm{O}$ desenvolvimento - repetimos - é apenas meio para a promoção do bem comum. Colocado o problema e em face dessa idéia primeira, verificamos desde logo os contrastes que o problema do desenvolvimento traz em sua essência.

Primeiro, o confronto entre os países chamados desenvolvidos e os chamados subdesenvolvidos, havendo quem ainda insira, entre as duas categorias, a dos países em desenvolvimento. Ainda se podem confrontar, entre as regiões do mesmo país, as desenvolvidas $\epsilon$ as subdesenvolvidas, o que é perfeitamente válido para o caso brasileiro.

Por outro lado, dentro da mesma região, as zonas rurais em contraposição às urbanas mostram algum desequilíbrio nas relações entre ambas, já que, a rigor, a produção rural deveria alimentar a cidade, e a cidade, por sua vez, deveria produzir máquinas para os trabalhos do campo. O equilíbrio dessas relações é, também, meta do desenvolvimento.

Mas o desenvolvimento não provoca só estas diferenciações tntre países, regiões ou zonas. Essa divisão é política ou geográfica. O mais importante, porém, para nós, é que o problema do desenvolvimento fêz crescer o contraste entre o capital e o trabalho. E não se trata só de contraste entre empregados e empregadores, entre ricos e pobres. $O$ pior é que há pessoas cada vez mais po- bres. A desigualdade cresce cada dia em quantidade (número de pessoas, que compõem a população) e em qualidade (intensidade da diferença apontada).

Essas desigualdades são ainda mais impressionantes hoje, porque o aperfeiçoamento dos meios de transporte diminuiu as distâncias entre países, entre estados e cidades, e assim o espaço da desigualdade tornou-se menor. Com isso, aproximaram-se os desiguais.

Esse problema social provocou e provoca ainda reações que podem explicar a inquietação atual, a agitação, e a insatisfação que se encontram em tôda a parte. Há hoje uma consciência viva da desigualdade entre os homens, consciência que se vai tornando cada vez mais viva. O que se chama, embora impròpriamente, de "massa" toma consciência, cada vez mais vivamente, dessa desigualdade. A assim denominada "politização" é cada dia maior.

De outro lado, para agravar o quadro social da nossa época, nota-se a inconsciência dêsses problemas por parte de um grupo de homens, os chamados "privilegiados" ou "conservadores", que se opõem à conscientização das "massas", assumindo uma posição, ou de radicalismo, ou de indiferença, uma e outra igualmente danosas, pôsto que afastam, ainda mais, a solução do problema social.

Dêsses "privilegiados" ou "conservadores", uns são inconscientes, outros são conscientes, mas dominados pela fadiga (fenômeno social, típico de nossos dias) ou pelo ceticismo (concepção de que é impossivel a solução). Mas o certo é que os que poderiam promover o progresso social caem na inércia ou na angústia, por vêzes compensadas por certa dose de esperança.

Nessas reações do ambiente, há diversidade de atitudes, mas há um convencimento dominante: reprovação e insatisfação diante da ordem de coisas na sociedade atual, em razão do domínio econômico. Apesar de geral, êsse convencimento, êsse juízo, êsse julgamento, não se traduz em atos. Os atos, as medidas para acudir a essa situação são muito poucas. Os mais freqüentes são atos não positivos, mas negativos: críticas, agitações, destruições. Construir é que falta. É muito mais fácil encontrar um demagogo do que um estadista (isso no plano político) que leve a uma solução.

Os esforços sérios, já feitos ou que se fazem, são parciais, reduzidos, em face dessa avalancha. Aqui cabem as reformas de estruturas. Reformas que se impõem. E há um dever de realizá-las surgindo desde logo o problema da opção, em face da direção, que essas reformas possam tomar.

Estabelecida como certa a necessidade de reformas, a primeira opção é a de que não pode haver modêlo no desenvolvimento econômico, que não pode ser visualizado como se fôsse uma préarquitetada maquete. $\mathrm{E}$ isso, antes de mais nada, porque, ao falar- 
se em desenvolvimento, está-se falando de homens, está-se lidando com homens, e não com pedras.

Entretanto, apesar de não se poder prefixar um modêlo, alguns princípios devem ser estabelecidos, para que se promovam as reformas. Do ponto de vista objetivo, portanto, o princípio é que não há limitações para a reforma. Não é essencial, por exemplo, que permaneça ou não o salário, mas pode-se descobrir outra forma de remuneração do trabalho. A priori, não há, pois, limitação quanto ao modêlo.

Mas a "Cidade Nova" se há de construir para atender ao homem, para realizar na plenitude as possibilidades do homem. Uma cidade, que não visasse a êsse objetivo, não deveria construir-se. E o princípio regente para nós será, então, o de que o homem deve poder realizar-se plenamente na "cidade" construída segundo as novas estruturas.

Êsse é, portanto, o fim, para o qual se devem encaminhar as reformas de estruturas. Êsse é o objetivo que deve ser assentado, sob pena de uma perturbação, de uma confusão maior que a de hoje.

E êsse fim é o homem, como ser social, não como unidade, mas dentro da vida social; é o homem no convívio social, sem qualquer retôrno ao individualismo. O homem é o ponto central da reforma, mas o homem como ser social. Cada vez que ocorrem essas emoções coletivas, em face dos progressos técnicos, quando a técnica abate o próprio homem, no instante em que parece não haver mais distâncias, ainda assim, o homem permanece objetivo final. Bem o reconheceu o pensador que disse: "Todo o universo, com essas maravilhas, que se descobrem cada vez mais, sem o homem é apenas uma imensidade vazia".

O mesmo pensamento vale para a reforma social. Uma reforma social perfeita, uma técnica perfeita, um progresso material que alcançasse a perfeição, seria uma imensidade vazia sem o ho. mem. É o homem que dá finalidade a essa reforma. Esse pensamento pode parecer estranho ao presente estudo mas, para quem lida com o Direito desde os bancos acadêmicos, é fácil constatar, com segura convicção, que o homem é o centro, o fim último, é a própria razão de ser do Direito.

Sem dúvida ,o plano moral não escapa ao jurista. Os valôres todos se subordinam a êsse valor: o valor "homem". As reformas que se propõem, via de regra, são propostas apenas em relação ao plano econômico: é o problema da propriedade, o problema da emprêsa, e outros correlacionados.

Parece certo, porém, que, se a reforma deve alcançar também e primeiro (cronològicamente) o plano econômico, a reforma não seria completa se não fôsse também política. Mas política não no sentido incompleto, de mudança de govêrno, de homens, da forma republicana para a monárquica, da presidencial para a parlamentar. Há necessidade de uma revolução política muito mais completa: os podêres políticos constituídos (Executivo, Legislativo e Judiciário) e os direitos individuais, funcionando dentro de um sistema político, em face da evolução - como aliás estamos presenciando nos dias atuais.

Ouiro aspecto a esclarecer é que quando se fala em reforma sem maquete não se quer dizer, necessàriamente, transformação total. Pode ser necessária uma transformação profunda, que atin. ja até muitas das raízes da sociedade atual, mas que não implique numa demolição completa. A História nos põe à mão valôres que não devem, de modo algum, ser destruídos, mas sim aproveitados.

Tais considerações, contudo, não significam que deve ser mantido o regime atual, quanto ao salariado, por exemplo. $\mathrm{O}$ salaria do - fique bem claro - não é um regime jurídico, dentro do qual funciona a relação de trabalho. O salariado é um regime econômico, que forma um regime social e o fato de tôda a nossa civiliza. ção se inspirar no regime do salariado não impede que seja alterado, porque é acidental.

Ainda não se encontrou outro regime melhor, desde a Revolução Industrial, mas a civilização avança para a substituição dêsse regime, porque êle conflita com aspectos humanos do trabalho.

Essas, algumas das considerações gerais para a apresentação da problemática que envolve o trabalho humano e, portanto, o próprio homem. O Direito está sofrendo transformações profundas, sendo impossível prever até que ponto irão essas transformações. Alguns pontos concretos, no que respeita a essas transformações, já podem ser vislumbrados. Nosso conceito de propriedade, por exemplo, deve sofrer uma retificação, deve ser corrigido naquilo que apresenta de mutilação de conceito. Antes, porém, que se opere sua reformulação, é necessário que se opere a "descoberta" do conceito.

Pode-se admitir que o problema seja meramente de retificação do conceito de propriedade, mas parece mais pròpriamente um problema de revelação, porquanto o conceito se apresenta mutilado.

Desde o fim do século XIX começou-se a insistir em que "a propriedade, sendo um direito, tem caráter privado, mas, ao mesmo tempo, desempenha uma função social". Essa nota, "funcão social" já se continha no conceito de propriedade, mas não tinha, ainda, sido "descoberta". Por essa época revelou-se, passando a ser afirmada. Nessa revelação, falou-se, primeiro, de "propriedade privada, mas com função social"; depois, de "propriedade com direção social". Mas êsses conceitos não satisfazem mais, e é neces- 
sário afastar do conceito de propriedade as deturpações do seu sen. tido próprio.

A verdade é que essa revisão do conceito de propriedade, ou melhor, de revelação do conceito de propriedade se deve aproximar da revisão do conceito de trabalho e ambas levarão a uma retificação do conceito de emprêsa.

A emprêsa capitalista moderna responde, em grande parte, pelo estado atual da sociedade.

Opõe-se-lhe a emprêsa estatal, em que o Estado se substitui ao empresário, mas êsse tipo de emprêsa cria outros problemas, sem resolver o problema fundamental.

A emprêsa comunitária, também preconizada como solução, traz o mesmo pensamento de comunidade, transformando a emprêsa numa pequena unidade comunitária. Não há ainda experiência suficiente dos resultados que possa produzir, porquanto as experiências já feitas são isoladas, e de âmbito muito reduzido. A emprêsa comunitária corresponde a um ideal $e$, ao que parece, não chegará a resolver o problema, embora se venha a praticá-la em escala maior.

Quanto à emprêsa popularizada, é idéia que vem sendo sustentada, entre nós, desde 1946, pelo Deputado Daniel Faraco. O capital de tais emprêsas deveria constituir-se através de ações dos seus empregados e do povo em geral. Assim, pela poupança, a população participa da emprêsa. É uma idéia em movimento, que realmente tem embasamento jurídico e que, no momento, marcha para a difusão.

O que, entretanto, parece certo, em meio a essa diversidade de tipos de emprêsa, é que a mesma, qualquer que seja a sua estrutura, não é apenas um ente econômico, mas é mais do que isso: é um ente social.

A emprêsa - para a Economia uma conjugação dos fatôres da produção (capital e trabalho, especialmente) - tem, no entanto, no fator trabalho, um elemento pessoal, insuscetivel de qual. quer combinação, no sentido químico, isto é, um fator imiscível com outros fatôres. É o fator homem, o fator humano, que conjuga-se com os outros, no sentido de integração, de colaboração rom os demais elementos da produção. Mas podemos notar sempre, na emprêsa moderna, a presença de um grupo social. E, pa. ra o Direito, como o concebemos, o que realmente importa, é o dado social, o dado humano.

Mesmo que não consideremos a reforma do conceito de emprêsa, tudo o que existe, no momento, sôbre o assunto, é suscetível de transformação. O salariado, por exemplo, - e já o citamos — não é a expressão de uma relação jurídica; é apenas a nota ca- racterística da civilização moderna, embora sempre acidental e conseqüentemente não essencial.

$\mathrm{O}$ ordenamento jurídico do trabalho, cujos primeiros sinais encontramos no século XIX e para cuja evolução contribuiram fatôres econômicos, sociais e políticos, chegou, hoje, a um ponto agudo nessa evolução, e a premência, a urgência na solução do problema pode ser claramente percebida em tôda a ordem jurídica, de modo geral, e na ordem jurídica do trabalho, de modo particular.

Hoje, ninguém mais sustenta o liberalismo. A discussão, acesa no século passado, sôbre se o Estado pode ou não intervir no domínio do trabalho, está encerrada. Essa fase foi superada. O problema atual é o da medida da intervenção do Estado, já que essa intervenção do Estado tende a tornar-se cada vez maior no domínio da Economia e, decorrentemente, no domínio do trabalho.

Deve essa intervenção ser total, de molde a só existir a emprêsa estatal, como nos Estados totalitários? $\mathrm{Na}$ emprêsa estatal, como é sabido, desde que inserida no contexto político de um Estado totalitário, êste assume a sua direção, afastando um dos sujeitos da relação social do trabalho. Claro está que não se preconiza uma intervenção dessa natureza, mas também é evidente que o Estado deve continuar intervindo no domínio econômico, não para se substituir às pessoas, que são os sujeitos da relacão de trabalho, mas para restabelecer a ordem, implantar o equilíbrio e a justiça social, coibindo abusos de qualquer natureza.

A estatização da emprêsa é admissivel e mesmo necessária em muitos casos, mas não se deve estender a todos os casos. A questão é a de saber até onde se deve ir na estatização da emprêsa. O princípio defendido pelo "cristianismo social", ou "socialismo cristão" é o princípio da subsidiariedade. O que a pessoa, individual. mente, não pode fazer, uma comunidade deve fazer; o que a comunidade não pode fazer, uma comunidade maior deve fazer; o que a comunidade maior não pode fazer, uma comunidade ainda maior deve fazer; o que esta grande comunidade não pode fazer, o Estado deve fazer. Se isso é passível de aplicação prática, resta sempre a questão da delimitação, caso a caso, do que cada uma dessas entidades pode, realmente, fazer.

Tal raciocínio mostra o estágio atual da evolução nesse assunto mas o certo é que a intervencão do Estado se realiza cada vez mais e, devido a isso, tôda a ordem jurídica se transforma, especialmente a do trabalho.

Não é suficiente, para nós, que a emprêsa assuma esta ou aquela estrutura. De momento, além dos dois aspectos já explanados - a automatização e o desenvolviment $o$ - o que se pode verificar é a melhoria das relações interpessoais no domínio do trabalho. 
Nesse particular, é altamente significativo o que se pratica nos chamados grandes países, como os Estados Unidos, a Inglaterra e outros. Observa-se, nesses países, um esfôrço pela melhoria das relações humanas no domínio do trabalho, mediante o estabelecimento, lado a lado da emprêsa, de poderosas fôrças sindicais, de tal sorte que se possa atingir o equilíbrio entre as emprêsas e os trabalhadores.

Mas, ao dizermos "poderosas fôrças", a expressão deve ser entendida como significando fôrças livres tanto do poder econômico, como do poder político. $\mathrm{O}$ sindicato deve ser, pois, uma expressão pura. E sòmente através da organização sindical autêntica se poderá encontrar o equilíbrio mencionado. Tal não se alcançará, se o sindicato estiver, de qualquer modo, sujeito ao poder "policial" do Estado, de cima, ou ao poder econômico da emprêsa, do lado. Equilíbrio com o desejado foi o que se conseguiu nas indústrias norte-americanas do carvão e do aço.

No Nazismo, tudo o que o Estado determinava - dizia-se correspondia ao bem supremo e, portanto, os sindicaots foram abolidos, como coisas sem sentido, já que, dentro da sistemática política adotada, não havia o que reivindicar face ao Estado. No Facismo, havia sindicatos, mas compunham corporações, legislando estas conforme a vontade do "Duce". No regime soviético, o sindicato se confunde como um dos órgãos do Poder do Estado.

$\mathrm{O}$ sindicato, no entanto, deve ser encarado como um instrumento precioso, destinado a fortalecer o elemento humano do trabalho, para, com essa fôrça sindical, poder enfrentar o chamado "poder econômico", ou seja, o empregador.

Essa fôrça, entretanto, não deve ser uma fôrça para a luta, para a guerra, para o conflito dentro do domínio do trabalho, mas sim deve ser uma fôrça tendente a estabelecer uma igualdade de fôrças, capaz de harmonizar, através de soluções justas e adequadas, a antinomia entre capital e trabalho.

A intervenção do Estado no domínio do trabalho deu origem a um conjunto de normas, que compõem o Direito do Trabalho. Êste tem por fim, imediatamente, a proteção do trabalhador. Mas o fim último a alcançar é a própria ordem econômica, social e política; é contribuir para a ordem social, para a paz social, para a justiça social.

Que se deve entender, no entanto, por justiça social?

$\mathrm{Na}$ recente Emenda Constitucional $\mathrm{n}^{\circ} 1$, inseriu,se, no tocante à ordem econômica e social, o seguinte:
"A ordem econômica e social tem por fim realizar o desenvolvimento nacional e a justiça social, com base nos seguintes principios:

I - liberdade de iniciativa;

II - valorização do trabalho como condição da dignidade humana;

III - função social da propriedade;

IV - harmonia e solidariedade entre as categorias sociais de produção;

$\mathrm{V}$ - repressão ao abuso do poder econômico, caracterizado pelo domínio dos mercados, a eliminação da concorrência e o aumento arbitrário dos lucros;

VI - expansão das oportunidades de emprêgo produtivo."

A ordem social e a ordem econômica devem, portanto, orientar-se pelo princípio da justiça social.

Pontes de Miranda, ao comentar a expressão, diz não se tratar, no caso, da justiça comutativa, no sentido clássico de dar a cada um o que é seu, mas sim da justiça distributiva. A justiça social é, pois, a própria Justiça.

No Direito positivo impera, porém, a idéia de uma justiça meramente comutativa (dou e recebo). Já a justiça distributiva manda dar a cada um o que lhe é devido, não segundo a lei, mas segundo sua condição social. E, portanto, a condição social que determinará na organização da sociedade e da emprêsa, o que cada um deve receber, presidindo a tudo isso o princípio da justiça social que é, por isso mesmo, muito mais do que a simples justiça comutativa.

A legislação do trabalho visa, portanto, a realizar a justiça social, valorizando o trabalho "como condição da dignidade humana", e procurando estabelecer a "harmonia e a solidariedade entre as categorias sociais de produção".

Mas, para que essas finalidades e êsses ideais perseguidos pela legislação do trabalho sejam alcançados, não basta insculpi-los, ainda que de forma sábia, lapidar e solene, nos textos constitucionais. É necessária também - e principalmente - a educação social, voltada para a "nova sociedade" que está surgindo, e que supõe, em primeiro lugar, um conhecimento profundo da nossa realidade atual, quer da parte dos empregados, quer, sobretudo, da parte dos empregadores, a quem, por possuírem maiores oportunidades, devem pertencer, também, responsabilidades maiores. 
E, acima de tudo, deve existir um ideal, uma crença, uma mística comum: a de que tudo isso se inspire na dignidade e na elevação đa pessoa humana - princípio sem o qual todos os ideais se destroem por si mesmcs. É o princípio da justiça social que deve inspirar essa mística. E, a par disso, devem-se recolocar os valôres nos seus lugares próprios, valorizando-se as pessoas e as coisas pelo seu conteúdo humano e espiritual e não apenas pelo interêsse ou vantagens que representam.

Nem no interêsse, nem muito menos no ódio, se devem inspirar as aspirações da justica e da harmonia sociais; mas, sim, na solidariedade humana, na compreensão humana, no ancor humano. Este é o princípio que deve inspirar as categorias de produção, na busca do desenvolvimento nacional e da justiça social. Tôdas as normas ae Direito tornam-se ineficazes se não forem valorizadas por êsse sôpro de amor e de solidariedade entre os homens.

Para finalizar, ainda numa homenagem ao eminente professor Eloy José da Rocha - de quem haurimos os ensinamentos aqui expostos - repetimos neste momento as palavras com que aquêle ilustre mestre concluía a exposição desta matéria, em sua cátedra na Faculdade de Direito:

"Se fôsse possível reunir num prato de balança as leis mais perfeitas do mundo, e no outro se colocasse uma rosa, a balança deveria pender para o lado da rosa, por causa do belo, por causa da vida, já que a rosa é a flor que mais expressão de vida tem.

E o homem, a vida, isso é que deve ser valorizado."

\section{PROBLEMÁTICA FILOSÓFICO-JURÍDICA ATUAL}

PROF. JACY DE SOUZA MENDONÇA

\section{A problemática geral da Filosofia do Direito}

No convívio humano, o Direito é um dado. Vive o homem, necessàriamente, segundo regras imanentes ao próprio convívio. Não as recebe, porém, apoditicamente, como algo indiscutível a que deve apenas submissão; problematiza o conteúdo da regra, a fim de verificar-se, e até que ponto, deve a ela realmente submeter-se. $\mathrm{Pa}$ ra isso, carece de compreendê-la, compreensão que permanece no limiar de um registro empírico ou ascende ao nível do conceito universal e necessário.

Descrita, assim, a posição existencial do homem face ao Direito, registram-se simultâneamente as duas atitudes fundamentais que, como sujeito, assume face a êste objeto: apreciá-lo em seu conteú do, em seu valor intrínseco, ou representá-lo conceitualmente. Em Filosofia do Direito, qualificam-se estas duas atitudes, respectivamente, como axiológica (ou deontológica) e lógica (ou conceitual) e delas exsurgem dois problemas fundamentais, redutíveis a duas perguntas: que vale o Direito? que é o Direito?

A resposta à primeira questão (referente ao valor do Direito) oscila, teórica e històricamente, entre duas hipóteses extremas: o valor do Direito emerge da fôrça da natureza ou da natureza da fôrça. É o esquema do diálogo entre SóCRATES e TRASÍMACO, de que dá notícia PLATÃO no Livro I da República. Diálogo intemporal. Os interlocutores nos servem como símbolo das perspectivas extremas possíveis em que o homem se põe face ao conteúdo

* Livre-docente de Filosofia do Direito. 